\title{
Naurun voima: Muistitietotutkimus huumorin merkityksistä Tikkakosken tehtaan paikallisyhteisössä
}

\author{
Lectio praecursoria 27.1.2018 Helsingin yliopistossa
}

Niina Naarminen

T

ikkakosken tehdasyhteisö kasvoi aseistaan tunnetun tehtaan ympärille viime vuosisadan aikana. Tehdas lakkautettiin taloudellisiksi ja tuotannollisiksi mainittujen syiden vuoksi vuonna 1991. Väitöskirjani käsittelee yhteisöllisen kulttuurin ja huumorin merkityksiä deindustrialisaation kokeneessa tehdasyhteisössä. Deindustrialisaatiolla tarkoitan lyhyessä ajassa tapahtunutta teollisten työpaikkojen vähenemistä ja samalla palvelualojen ja erityisesti hoitotyön tarpeen lisääntymistä.

Autoetnografisen tutkimukseni pääasiallinen aineisto koostuu tallentamistani muistitietohaastatteluista alkaen vuodesta 1996 jatkuen viime vuosiin saakka. Olen käyttänyt tutkimusaineistona myös omia muistojani ja havaintojani, sillä olen itse tutkimani

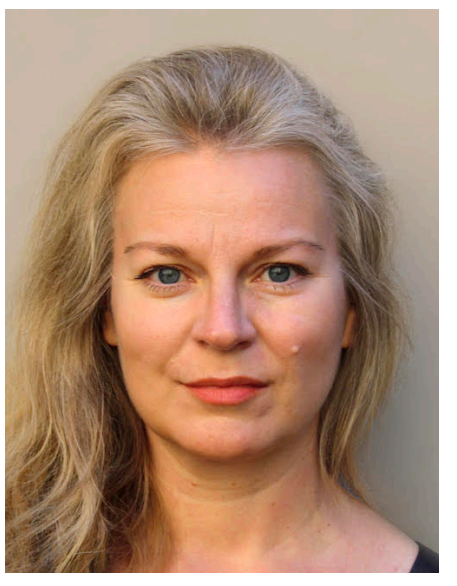

Niina Naarminen yhteisön entinen jäsen. Tässä tapauksessa juuri tämä tekee työstäni autoetnografisen. Lisäaineistoina tutkimuksessani ovat yhteisöä, muistitietoa ja perinnettä koskevat julkaisut, arkistoaineistot, sekä esimerkiksi päiväkirjat ja kirjeet. Tallentamieni haastatteluiden lisäksi sain arvokasta muistitietoa tehtaalaisista Suomalaisen Kirjallisuuden Seuran äänitearkiston maakuntakeruuhaastatteluista, jotka on tallennettu 1970-luvulla. Kansan Arkistossa puolestaan on tallennettuna Tikkakosken Työväennäyttämön harrastajanäyttelijöiden kerrontaa, ja Työväen Arkistossa 1960-luvulta lähtien muistitietotoimikunnan keruun tuottamaa tietoa vuoden 1918 tapahtumista paikkakunnalla.

Tikkakosken tehtaalaisia koskevaa muistitietotutkimustani ohjaa mikrohistoriallinen näkökulma. Mikrohistoriallinen tarkastelutapa yleensä pyrkii heijastamaan pienistä yksityiskohdista saatua tietoa suuriin kokonaisuuksiin ja päinvastoin. Se analysoi esimerkiksi yksittäisiä henkilöitä ja heidän toimintatapojaan yhteisönsä jäseninä omassa ajassaan ja paikassaan. Yhteiskunnan ja yhteisöjen suuret muutokset heijastuvat väistämättä yksilöiden elämään, mutta yksilöiden kokemukset nitistyvät helpommin yhteiskunnan rattaiden alle piiloon. Muistitieto tuo meitä ympäröivän yhteiskuntamme muutoksista tietoa, jota ei saa tilastoista. 


\section{Muistitiedon haasteellisuus}

Haastateltavani puhuivat mielellään työstään tehtaalla. Erityisesti eläkkeellä olevat työntekijät maalasivat eteeni värikkään kuvan menneisyyden kullanhohtoisesta onnelasta, jota johdettiin oikeudenmukaisesti ja tasavertaisesti. Heidän arkensa 1990-luvun lopulla ja 2000-luvun alkuvuosina oli virkeää ja aktiivista. He korostivat sosialidemokraattien ja kansandemokraattien poliittisten kiistojen olevan historiaa ja inmettelivät vuoron perää, miksi olivat joskus ylipäätään riidelleet politiikasta. Eläkeläiset elivät yhteisöllistä ja taloudellisesti turvattua elämää. Huumori ja nauru olivat keskeisellä sijalla heidän kerronnassaan.

Tehtaalla 1990-luvun alussa irtisanotut ja työttömiksi jääneet tehtaalaiset muistelivat myös huumoria ja naurua tehtaalla, mutta toisin kuin eläkeläisten arjessa, heidän yhteisöllisyytensä entisten työtovereiden kanssa mureni vähitellen. Kerronnassa toistuivat hylätyksi tulemisen teemat ja yhteisestä huumorista ja naurusta työtovereiden kanssa puhuttiin kuin hetkistä menetetyn rakkaan kanssa.

Aika ei paranna haavoja, mutta muuttaa yksilötasollakin näkemyksiä koetuista asioista. Tapahtumat ja muutokset kunkin ihmisen elämässä muovaavat muistoja ja ajattelutapaa. Tarkastelen tutkimuksessani myös omia kokemuksiani ja muistojani ja analysoin niitä nykykontekstissa. Muistot ja mielleyhtymät kokemastani huumorista ja pilailusta yhteisössäni - yhtä lailla kuin esimerkiksi ääniin liittyvät muistot - muuntuvat ja vaihtelevat ajan ja kontekstin myötä. Tämä on pidettävä mielessä myös haastateltavieni vastauksia tulkitessa. Muuntuvuus on muistitiedon erityinen ominaisuus ja tekee sen haasteelliseksi. Tutkijan on osattava tulkita ja analysoida muistojen muuntuvuuden syitä.

Analyyttinen kehys yhdistää työssäni muistitietotutkimuksen, folkloristiikan ja yhteiskuntahistorian tutkimusten metodeja. Tutkimuksessani tarkastelen identiteettejä ja niiden muutoksia Tikkakosken tehdasyhteisössä politiikkaa ja huumoria korostavan perinteen kautta.

\section{Kiistämisen kulttuurin ylpeyttä ja nöyryyttä}

Työväenkulttuurin karnevalistisuus ja itseironian muodot ilmentävät kaksijakoisesti uhmakasta ylpeyttä ja samaan aikaan nöyryyttä. Huumori ja pilailu Tikkakosken tehdassalikulttuurissa olivat keskeinen osa yhteisöllistä perinnettä. Erityisesti ulkopuolelta yhteisöön tulleiden ja vähemmistönä työskennelleiden naisten haastattelut antavat tietoa omaehtoisen huumorikulttuurin tuottamasta sisäpiiriylpeydestä, mutta paljastavat samaan aikaan rakenteellista syrjintää, joka kohdistuu erityisesti heihin, joilla ei ole ollut yhteisön tukea. Ristiriitainen tietoisuus omasta asemasta työläisyhteisössä toistaa haastatteluissa myös tätä kaksijakoisuutta. Sen yksi ilmenemismuoto on asenne tehtaan johtajistoon yhtäältä ihaillen ja toisaalta heistä vitsaillen. Tehdaspaternalismina tunnetun ilmiön periaatteiden mukaisesti johtajisto tuki Tikkakoskella, kuten monissa muissakin maaseututehtaissa, isällisesti yhteisön kasvua ja hyvinvointia - liiketoiminnan tavoitteiden tukemiseksi. Haastatteluiden, arkistoaineistojen ja aiempien paikallisjulkaisujen perusteella on korostettava, että pelkästään suunnitelmallisesta hyväksikäytöstä ei ainakaan kaikkina vuosikymmeninä ole ollut kysymys. Pyrkimys tasavertaisuuteen on näkynyt esimerkiksi johtajiston tavassa tukea työläisten järjestäytymistä antamalla yhdistyksille tehtaan rahoittamat kokoontumistilat. Näin ei kuitenkaan ollut tehtaan alkuvuosikymmeninä, vaikka haastatteluiden perusteella johtajat näyttäytyvät aivan erityisinä hyväntekijöinä juuri 1890-luvusta 1920-lukuun asti. Muistitieto 
on ristiriitaisinta vuotta 1918 koskien. Haastatteluiden ja tilastotietojenkaan mukaan Tikkakoskella ei käyty sisällissodan aseellisia kamppailuja. Juuri tuona vuonna tehtaalla aloitettiin aseiden tuotanto itsenäisen Suomen armeijaa varten. Näin ollen Tikkakosken poliittisesti aktiivisinakin tunnetut sosialidemokraattiset työläiset tekivät aseita valkoista osapuolta edustavalle taholle. Kenenkään haastateltavan kerronta ei tuonut esiin tätä seikkaa, lukuun ottamatta yleisluontoista vihjausta "vaikeasta vuodesta 1918". Sen sijaan useissa haastatteluissa korostettiin tehtaan johtajiston "suojelleen" työntekijöitä joutumasta vangituiksi poliittisista syistä. Haastatteluissa kiellettiin vangitsemisia tapahtuneen lainkaan. Kuitenkin Työväen Arkiston muistitietotoimikunnan keruun tuottama tieto tehtaan entiseltä työläiseltä tuo esiin toisen totuuden. Alun alkaen Venäjällä aseseppäkoulutuksen saanut mies tuli Tikkakosken tehtaaseen töihin vuonna 1919 ja kertoi tehtaalle palanneen samoihin aikoihin luurangoiksi laihtuneita työmiehiä vankileireiltä. Miehen mukaan työläisten välit johtajistoon olivat kireät. Nuori mies ei työskennellyt tehtaassa pitkään ja muutti Tikkakoskelta pois.

Tikkakoskella monen sukupolven ajan työskennelleet tehtaalaiset kertoivat omaa totuuttaan tehtaasta ja sen perhemäisestä yhteisöstä sukupolvesta toiseen. Siihen ei kuulunut vuoden 1918 sota muussa merkityksessä kuin turvapaikkana. Siihen kuuluivat ilo, nauru ja Tikka-henki, joka merkitsi tehtaalaisten yhteishenkeä ja joka haastatteluissa mainittiin ensimmäisten johtajien ansioksi. Edellyttikö sovinnollinen nauru vaikeuksista vaikenemista yhteisössä? Vanhimpien haastateltavieni ja arkistohaastatteluiden kerronnasta käy selväksi, että ennen torpparilakia lähiseudun, erityisesti Tikkamannilan kartanon isäntä oli ollut torppareille ja alueen köyhälistölle häikäilemätön. Verrattuna kartanon patruunan käytökseen uuden tehtaan patruunat olivat hyväntekijöitä. Köyhälistön luottamus tehtaan patruunoihin syntyi ja kasvoi nopeasti paikkakunnan hyvinvointia edistävien investointien vuoksi. Johtajisto ruokki luottamusta ilmeisen hyvin tuloksin, jos ja kun myös vuoden 1918 tapahtumat muistetaan yhteisössä edelleen heitä suosivassa valossa.

\section{Karnevalismia ja veijareita}

Työläisten omaehtoinen huumorikulttuuri ihaili patruunoita, jotka osasivat elää työläisten yhteisössä työläisten tapojen mukaan. Tarinoiden neuvokkaaksi mielletty patruuna hoiti työläisten yksittäisiä juopporettelöintejä viemällä henkilökohtaisesti rettelöitsijät putkaan. Sama patruuna ratkoi työläistensä perheväkivaltatilanteita ja muita keskinäisiä riitoja lyömällä henkilökohtaisesti pahemmaksi arvioimaansa osapuolta omin nyrkein. Ja edelleen: sankaripatruuna hiihti tehtaan hiihtokilpailuissa herraskaisesti silinterihattu päässään ja sikari hampaissaan tehden itse itsestään pilaa. Epäsovinnaisuus ja itseironia olivat erinomainen yhdistelmä pohjana tehtaalaisten huumorikerronnalle. Samankaltainen kerronta on ollut tyypillistä jo agraariajan Suomessa. Teollisuustyöntekijöiden huumori on toistanut samoja kerronnan aiheita kuin esimerkiksi Seppo Knuuttilan tutkimat isäntä ja renki -kaskut. Tehtaalaisten muistitiedosta paljastuu yhtäläisyyksiä myös esimerkiksi Satu Apon tutkimiin teemoihin vanhoista suomalaisista, aikuisille suunnatuista kansansaduista, jotka käsittelivät suorasukaisesti groteskia ja seksuaalista huumoria. Tämän kaltainen mentaliteetti ulottaa juurensa kauas menneisyyteen jo aiemmin mainitsemaani karnevalismiin. Huumori ja nauru yhteisön sisällä ei kohdistu ainoastaan ulospäin, vaan ironisoi yliampuvasti myös itseään. Kerronnassa kuulijalle luotu kuva tehtaan oikeudenmukaisesta patruunasta pamputtamassa tuhmaa työntekijää päähän, tai sama hahmo hiihtämässä sikari hampaissaan, toisintaa myös kuvaa keskiaikaisesta ja sen jälkeisestä eurooppalaisesta komediateatteriperinteestä. 
Omaa voimaa ja oveluutta osoittavat tehtaalaisten kerronnassa puolestaan veijarihahmot. Nämä neuvokkaat ja ovelat hahmot ovat kertojasta riippuen yleensä poliittisen huumorin keskiössä. Kun kertojana on sosialidemokraattinen henkilö, hän huijaa ovelasti kommunistia. Ja kun kertojana on kommunisti, hän korostaa omaa neuvokuuttaan ja pilkkaa demarin kömmähdystä. Oman voiman ja sanan säilän julkea korostaminen toistuu naisten ja miesten välisessä huumorissa, jossa on nähtävissä samankaltaisia "servaamis"-piirteitä kuin rap-kulttuurissa. Tehtaalla huumorin aloite tuli haastatteluiden mukaan useimmiten miehiltä ja naisten piti osata vastata siihen samalla mitalla ja mielellään paremmin. Haastatteluiden perusteella on nähtävissä, että tähän pilailuun osallistuivat enimmäkseen naiset, joilla oli tiivis tukiverkko tehtaalla mahdollisesti jo usean sukupolven ajan. Yhteisöön muualta muuttaneet joutuivat sen sijaan helposti syrjään tai toisaalta joskus kokemaan seksuaalista häirintää. Suurinta auktoriteettia huumoriperinteessä nauttivat iäkkäät ja tehtaalla kauan työskennelleet naiset, joista muutamat olivat myös aloitteellisia pilailuun.

\section{Yhteenveto}

Tehdassalikulttuuri, kiusoittelu ja pilailu taukoharrastuksineen sekä kahvi- ja ruokatuntikeskustelut ylläpitivät Tikkakosken tehtaalaisten huumoriperinnettä ja yhteishenkeä kymmenien vuosien ajan. Tämän patruunat tiesivät alusta asti: työntekijöiden hyvä yhteishenki olisi myös paras pohja luottamukselle. Työntekijöiden luottamus johtajiin romahti lopullisesti vasta tehtaan lakkauttamisen myötä. Irtisanotut haastateltavat tunsivat tulleensa petetyiksi - eivät ainoastaan tehtaan lakkauttamisen aikaan, vaan sukupolvien ajan. Työttömät kokivat, että sovinnollisuudella oli ollut hinta, jonka maksajiksi he joutuivat.

Tutkimus osoittaa haastatteluin, että työn ja yhteisön menettäminen toi mukanaan häpeän kokemuksia taloudellisten ja terveydellisten ongelmien lisäksi. Haastateltavista he, jotka olivat jääneet eläkkeelle tehtaan lakkauttamista ennen, pysyivät virkeinä pitäen aktiivisesti yhteyttä entisiin työtovereihinsa. Irtisanotut tehtaalaiset taas vieraantuivat vähitellen entisestä yhteisöstään eivätkä ehtineet pätkätyöpaikoissa saada tehtaalla vallinneiden sosiaalisten suhteiden kaltaisia kontakteja. Työttömät ikävöivät tehdastyöstä eniten "työporukkaa ja naurua". Niiden menettäminen oli työläisten elämässä käännekohta henkilökohtaisella mikrotasolla, mutta osoittaa myös yhteiskunnassa makrotason muutosta.

Deindustrialisaatio on muuttanut työväen kansanomaista kulttuuria lyhytaikaisten pätkätöiden myötä. Yhteisöllisen naurun ja ylpeyden tilalla on häpeää oman identiteetin kadottamisesta ja pelkoa omasta tulevaisuudesta. Mentaliteetit eivät muutu nopeasti. Kun yhteiskunta muuttuu vauhdikkaasti ympärillä, on ihmisten vain sopeuduttava muutoksiin. Ilman yhteisöä ei voi olla yhteisöllistä kulttuuria. Yhteisöllisyys on kuitenkin saanut uusia muotoja esimerkiksi sosiaalisen median kautta. Sukupolvien ajan kasvatuksen ja elinympäristön myötä muodostunut mentaliteetti kantaa mukanaan opittuja elementtejä sukupolvesta toiseen. Ne muuttuvat vähitellen. Vaikka yhteisöllinen nauru on makrotasolla työläisiltä osittain katkennut, on kansanhuumorimentaliteetista silti jäljellä vielä jotain, joka saa uusia muotoja jatkuvasti. Tätä toivon voivani tutkia jatkossa lisää.

Naarminen, Niina 2018: "Naurun voima": Muistitietotutkimus huumorin merkityksistä Tikkakosken tehtaan paikallisyhteisössä. Helsinki: Työväen historian ja perinteen tutkimuksen seura. https://helda.helsinki.fi/handle/10138/231260 


\section{Lähteet}

\section{Arkistoaineistot}

Työväen Arkisto (TA)

Vilho Orenius. Työväen muistitietokokoelma, TMT 134, 65-67, 258/29-63 ja 258/57, 1920-luku/1919-30.

\section{Kirjallisuus}

Apo, Satu 1986: Ihmesadun rakenne. Juonien tyypit, pääjaksot ja henkilöasetelmat satakuntalaisessa kansansatuaineistossa. Helsinki: SKS.

Bahtin, Mihail 2002: François Rabelais. Keskiajan renessanssi ja nauru. Helsinki: Taifuuni.

Gramsci, Antonio 1985: Selections from the Prison Notebooks. New York: International Publishers Co.

Knuuttila, Seppo 1992: Kansanhuumorin mieli. Kaskut maailmankuvan aineksena. Helsinki: SKS.

Peltonen, Ulla-Maija 2003: Muistin paikat. Vuoden 1918 sisällissodan muistamisesta ja unohtamisesta. Helsinki: SKS.

Portelli, Alessandro 1991: The Death of Luigi Trastulli and Other Stories. Form and Meaning in Oral History. Albany: State University of New York Press.

Thompson E. P. 1996: Herrojen valta ja rahvaan kulttuuri. Valta, kulttuuri ja perinnäistavat 1700-1800-luvun Englannissa. Tampere: Gaudeamus.

Willis, Paul 1977: Learning to Labour. How Working Class Kids Get Working Class Jobs. Aldershot (Hampshire): Gower Publishing Company.

Filosofian tohtori Niina Naarminen työskentelee tällä hetkellä post doc -tutkijana Elävä Suomenlinna. Yhteisöjen muuttuva kulttuuriperintö -tutkimushankkeessa. 